\title{
The Conquering Strategies of Oligopoly Firms. A review on entry Strategies of Tesco Company PIc in the UK and beyond.
}

\author{
Audu, Amos Anyesha., Danjuma Naisla Hassan., Habakuk Aboki, \\ ${ }^{I}$ School of Basic and Remedial Studies,Department of Social Sciences, Business Management Unit, Nasarawa \\ State Polytechnic, P.M.B 109, Lafia-Nigeria. \\ ${ }^{2}$ Department of General Studies, Nasarawa State Polytechnic,P. M.B 109, Lafia-Nigeria. \\ ${ }^{3}$ Department of Pre-ND, Nasarawa State Polytechnic,P.M.B 109, Lafia-Nigeria.
}

Abstract: The strategies of oligopoly firms usually pull high sales since price rigidity is the watch word, while none price strategies such as advertisement, marketing, personal selling, distribution, branding and club card with constant. While, the rivalry depends on price elasticity of demand with the gradient lied in kinked demand graph in the work. And the threat of entry usually high in the UK grocery market with Tesco firm possessing high opportunity in the industry over rivals.

\section{Introduction to Tesco Company Plc.}

Tesco Plc., founded in 1919 by Jack Cohen and based in Cheshunt UK. Tesco and its subsidiaries on grocery retails sales primarily: food, clothing and electrical products and as a merchandise firms. Others includes: retail banking, financial insurance services, and data analysis, distribution and property operations. The Company operates in UK, China, Czech Republic, The republic of Ireland, India, Malaysia, Poland, Slovakia, South Korea, Thailand, Turkey, and US. Tesco sells approximately 5,000 retail stores and through the internet's (Nationwide, 2012). The business grown over the years. (Rugman and Collinson, 2012) inferred, that approach of consumers on products and services, depend on what the consumer actually wants and is certain about, decisions made by consumers are rational, and are tailored toward utility derivation. Tesco strategies apart from increasing or reducing price: price rigidity: these strategies edge Tesco over its competitors. Tesco's non-pricing, strategies includes: Advertisement, Strategic Marketing, the Club Card, and Strategic Sales, Distributions, Marketing etc. The irony of Oligopoly market is cost do not affect price in other to avoid "war" and low sales. This because the few firms in'price the industry depends on each other (interdependency), been the derive of oligopoly market (Tesco plc, 2012). While other area to analyze and discuss are: Market Ratios, kinked and Oligopoly behaviors, actions of rivals in the market are: the UK Grocery size and Market Performance, Perfect Competition, Competition Commission and Tesco response, Pricing and Non-Pricing Strategies: Examples of "the Big Price Drop Campaign" rivalry response, Demand Estimation in relation to Club Card and Tesco data collection through Club Card. Others are Demand Estimation and Theory of Demand, up to date Data on Sales and Price Performance for five (5) years: Data and Graph in London Stock Exchange of Tesco, Morrison's and Sainsbury's. While the main trend/movement in the Stock for the firm is briefly mentioned and compare with the relative Share Price Performance of FTSE ALL-Share index.

However, Tesco Market Share for five (5) compare with other National Groceries such as Schwarz 9.4\% (Germany), Costco 9.1\% (US), Kroger 7.1\% and Tesco 6.7\% (UK) and the work is concluded with the last aspect which addressed areas such as: Reasons for Tesco expansion abroad, entry strategies to international markets and other geographical region is considered. While diagrams and graphs were appropriately acknowledge and the reviewed concluded with list of references as sources. 
UK Grocery Market ending $30^{\text {th }}$ September, 2012.

KANTAR UL RDPANEL MARKET SHARE - TOTAL TILL ROLL

\begin{tabular}{|c|c|c|c|c|c|}
\hline & \multicolumn{2}{|c|}{$\begin{array}{l}12 \text { Wee ks to } 2 \text { October } 2011 \\
\text { £OOOs }\end{array}$} & \multicolumn{2}{|c|}{12 Weeks to 30 September 2012} & $\begin{array}{c}\text { change } \\
96\end{array}$ \\
\hline Total Till Roll & $29,794,990$ & & $30,672,930$ & & \\
\hline Total Grocers & $22,529,920$ & $100.0 \%$ & $23,415,190$ & $100.0 \%$ & 3.9 \\
\hline Total Multiples & $22,021,380$ & $97.7 \%$ & $22,908,800$ & $97.8 \%$ & 4.0 \\
\hline Tesco & $7,021,897$ & 31.296 & $7,253,715$ & $31.0 \%$ & 3.3 \\
\hline Total Asda & $3,961,986$ & $17.6 \%$ & $4,097,743$ & $17.5 \%$ & 3.4 \\
\hline Asda & $3,916,999$ & 17.496 & $4,097,743$ & $17.5 \%$ & 4.6 \\
\hline Netto & 44,988 & $0.2 \%$ & . & $0.0 \%$ & -100.0 \\
\hline Sainsbury"s & $3,649,907$ & 16.296 & $3,853,232$ & $16.5 \%$ & 5.6 \\
\hline Morrisons & $2,665,176$ & 11.896 & $2,664,079$ & $11.4 \%$ & 0.0 \\
\hline The Co-operative & $1,601,422$ & $7.1 \%$ & $1,587,295$ & $6.8 \%$ & -0.9 \\
\hline Co-operative & $1,594,977$ & $7.1 \%$ & $1,587,291$ & $6.8 \%$ & -0.5 \\
\hline Somerfield & 6,445 & $0.0 \%$ & 4 & $0.0 \%$ & -99.9 \\
\hline Waitrose & 997,508 & $4.4 \%$ & $1,090,608$ & $4.7 \%$ & 9.3 \\
\hline Aldi & 550,405 & $2.4 \%$ & 690,000 & $29 \%$ & 25.4 \\
\hline Lidı & 578,372 & $2.6 \%$ & 640,695 & $2.7 \%$ & 10.8 \\
\hline Iceland & 421,733 & $1.9 \%$ & 460,496 & $2.0 \%$ & 9.2 \\
\hline Farm Foods & 136,758 & $0.6 \%$ & 134,488 & $0.6 \%$ & -1.7 \\
\hline Other & 436,213 & $1.9 \%$ & 436,447 & $1.9 \%$ & 0.1 \\
\hline ymbols \& Ind & 508,547 & $2.3 \%$ & 506,391 & $2.2 \%$ & -0.4 \\
\hline
\end{tabular}

Source: Kantar World Panel, ( 2012).

Kantar world panel, (2012). Analysis for 12 weeks ending $30^{\text {th }}$ September, 2012. The UK Oligopoly Grocery Market Share is: Tesco 31.0\%, Asda 17.5\%, Sainsbury's 16.5\%, Morrison 11.4\% respectively. The current Market Share of Tesco is higher, than its rival's reasons are: few Firms in the UK grocery market serving many consumers, each Firm believes rivals will not respond to price increase and wouldn't yield to price hike and barriers to entry into this market are high.

\subsection{Market Concentration Ratio:}

This measure the concentration of market share held by suppliers in the market. "It is the percentage of total market sales accounted for by a given number of leading firms." Thus firm concentration ratio is the total market share of firms with the largest market shares (About.com, 2012). The Market Concentration Ratio is Tesco $=7,226,084+$ Asda $=4,146,122+$ Sainsbury's 3,859,792 + Morrison's $=2,695,266 / 100 / 23,490,80=76.3 \%$ The market concentration ratio Tesco, Asda, Sainsbury's and Morrison's is $76.3 \%$.

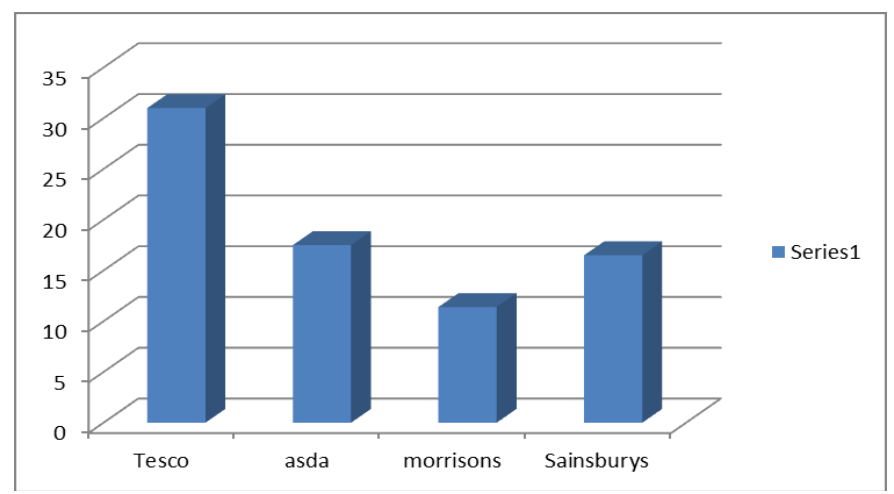

Source: Kantar world panel, (2012).

\subsection{Oligopoly.}

In this industry firms shares are highly concentrated. This market is best measure by market concentration ratios others includes: numbers of firms each in this market is Large relative to the total industry (interdependency features) and price rigidity are power in the market and ' fear of price war ''(Baye, 2010).

\subsubsection{Oligopoly theoretical characteristics.}

Interdependency is when price decision of one firm in the industry is consider by other firms (cross elasticity) increase or decrease to, "'avoid price war", few sellers in the industry and barrier to entry (difficult), identical, homogenous products exist in this market. While, Kinked demand, has no uniformity on the demand curve of oligopoly for each rival in the market may behave in non-conformity, for example the cartel form by OPEC, some members country act ( non-conformist dragging the graph down ward and kinked.

However, Oligopoly firms are more into strategic means of high sales since their price is rigid. Non price strategies such as: advertisement, marketing, and personal selling distribution and branding with constant price 
(Baye, 2012). In this market, the rivalry reaction depends on the price elasticity of demand which in the gradient depends on change which at this position demand is kinked as illustrates graph below:

A Kinked Demand Curve, illustrating Firms actions in the Market.

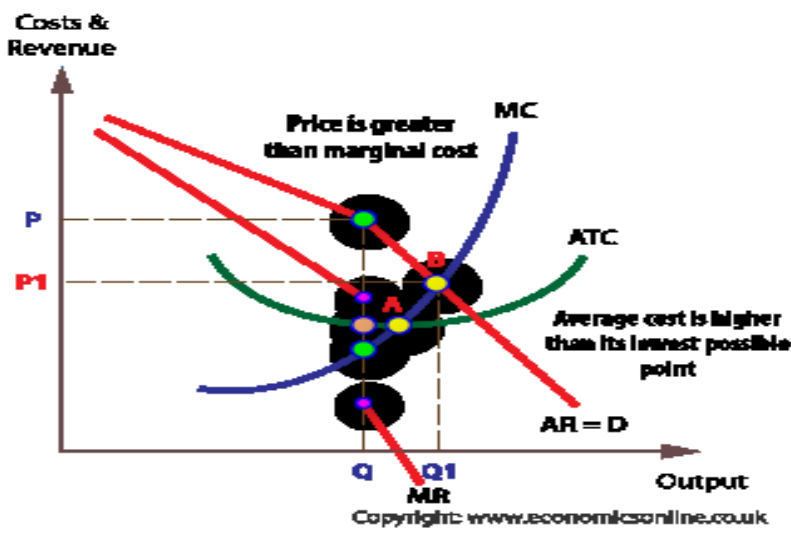

Source: Economics online, (2012)

\subsubsection{Maximising Profit.}

If the $\mathrm{MR}$ and $\mathrm{MC}=$ Profit Maximization $\quad: \quad \mathrm{MC}=\mathrm{MR}$

When $M C=M R=$ Profit MX at Point $P$. When MC moves to the vertical portion, the affected price is minimal and consumers will not gain the benefit of any cost reduction (Economics online, 2012).

\subsubsection{Oligopoly Underline Behaviour.}

The underline Behaviour in UK Grocery Market: Tesco, Asda, Sainsbury's and Morrison's Market Shares $76.3 \%$, Tesco 30.0\%, (high player). Been Oligopoly with key component of (Mutual Interdependency) and price rigidity, when cost changes, May breach example (OPEC) such firm may loss both customers and profit. Thompson and Martin (2005) posit that the threats of new entrants is usually high in the market where the main player has higher opportunity in the industry over rivals, any attempt of entry by any other firm in the industry, could result to reaction and counter-reactions. Tesco relied on Non-Pricing Strategies such as Advertisement, Marketing, and Club Card etc. Strategies are used by Firms but some Strategy outweigh.

\section{Demand and Action of Rivals in the Market.}

Point L of Po Demand Curve $\mathrm{C} 1$ is based on Assumption that rivals will match any Price change, while $\mathrm{C} 2$ is based on Assumption they will not match Price change. Reason, given Price reduction, firm sell more if rivals do not cut Prices $\mathrm{C} 2$ than it will lower their Prices C1.In reduction, price increases quantity demanded only slightly when rival respond lowering Price: Similarly, if a given price increase firm sale more when they maintain Price C1 then Prices at $\mathbf{C 2}$ will be maintain. Tesco Pricing and selling Strategies has helped, against its Competitive rival in the Oligopoly Market over: Asda, Sainsbury's Morrison's and others (Baye,2010). Tesco edge its rivals in the industry $\mathrm{C} 2$, existing or low prices in the industry.

\section{Demand and Action of Rivals in the Market}

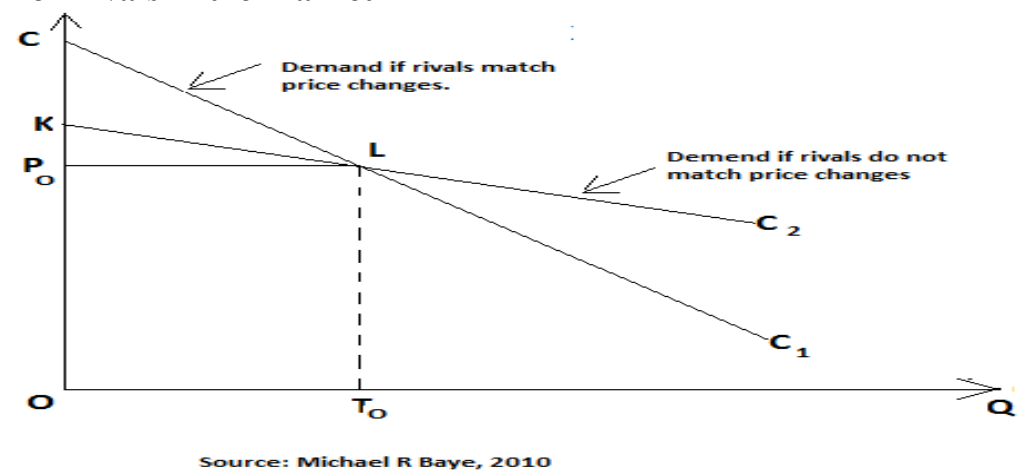




\subsubsection{UK Grocery Market.}

The Market worth $£ 156.8$ billion in 2011, an increase of 3.8\% in 2010 Food and beverage expenditure accounts for 53p in every $£ 1$ of retail spending. The report account for 88,441 Grocery Stores in the UK. These sectors exist in the UK Grocery they are: (i) convenience stores ( ii) traditional retailers (iii) super markets.

(iv) super Stores (v) hyper markets and (vi) online channel sales via internet (IGD, 2012).

Source: IGD, (2011).

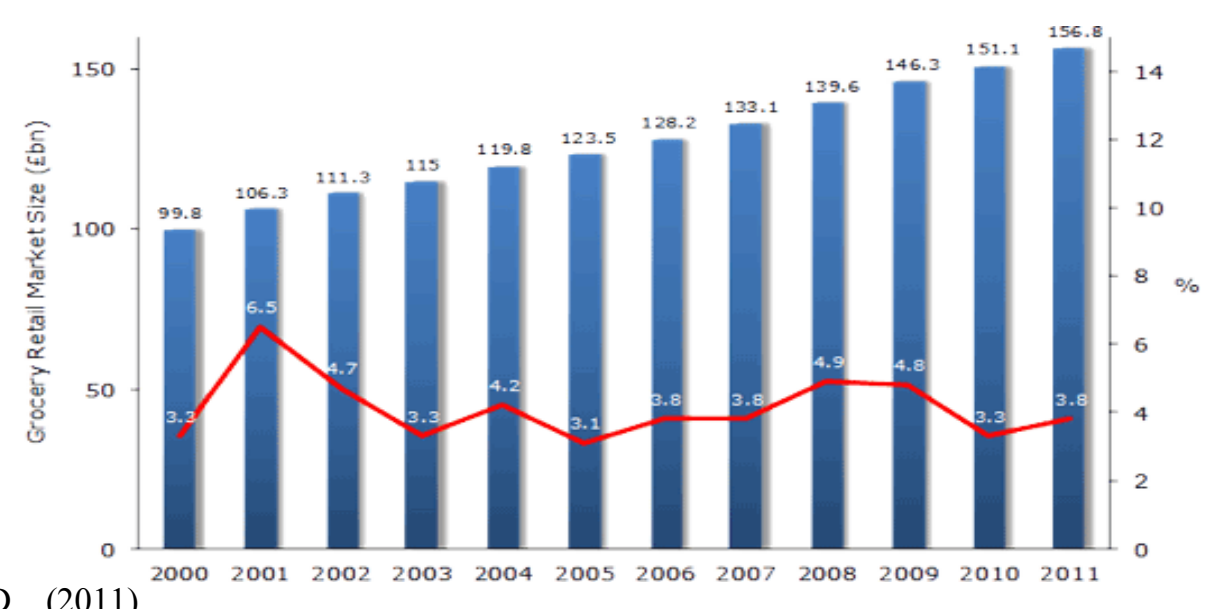

\section{Oligopoly Market}

An Example of UK Grocery Market:In oligopoly, few firms are largely relative to the total industry, it's the most interesting in all market structures relating it to UK Oligopoly Grocery Market. Firms in oligopoly setting are difficult to manage. In the Market, Managers must consider the effects of all decisions and actions of other firms in the industry, and this actions of other firms in the industry will enhance great impact on the manager's optimal decisions ( Baye,2010) Hence: The Market and its entry principles is complex. The Market is interdependence on each other of where several firms selling differentiated products or services and competition on price is high. Manager decision in the industry is very important, and firms strategy in the industry must be but into consideration. However, at low price firms, will lower their Prices or keep existing prices. An optimal decision must be taken by manager, this is typical situation experienced by the UK Grocery Market ( Baye, 2010).

\subsubsection{Perfect Competition:}

A Perfect Competition is a Market where the degree of perfection in the Market allows only one single price to prevail and exist in the market. In real life situation complete percent Price perfection is difficult mostly theoretical (Akrani, 2010). Perfect Competition Assumption: Large number of Firms, identical products and high Consumers, free entry, new firms to enter the market and existing ones to leave, no advantages of existing firms. it assumes buyers and sellers have perfect information about market condition (Rittenberg and Tregarthen, 1996).

\subsubsection{Oligopoly and Perfect Competition in UK Grocery Market.}

The nature of prices in the UK grocery market is a challenge to Competitors. Tesco strategies increase sales and revenue for the firm even if Price remains constant. While consumers have knowledge of all Firms in the Grocery Market transaction. High risk and difficult for new entrants penetrating the UK grocery market, the economies of scale, switch cost of firms intending to enter the Market etc. Example Tesco captured the UK Markets with multiform strategies of non-pricing strategy (Thompson and Martin, 2005). However, characteristics that distinct perfect competition is: Differentiation which undermines Perfect Competition Assumption by creating a barrier for Tesco response to price increase. While, in real life, Tesco have distinct itself by differentiation and only largely relative to the total industry as Oligopoly Firm. An important implication of this model to real world competition is: In UK grocery market, Tesco Total Marginal Cost (TMC), will not affect its profit- maximization level of output. This is contrary to monopolistic firms, which increase output when Total Marginal Cost (TMC) decline (Baye, 2010).

\subsubsection{Tesco Appeal.}

The Competition Appeal Tribunal upheld the appeal brought by Tesco challenging part of the Competition Commission's final report into the supply of groceries: In the CC's recommendation: A "competition test" to preventing the market dominance of large retailers: The competition appeal tribunal 
recommends the competition test and directed the competition commission to retake making the UK groceries effective. However, the features that prevent, competition are: high concentration numbers of local markets which long persisted barriers to entry or expansion in certain local markets which limit construction of new ones also barriers to entry caused by control of land in some highly concentrated markets by incumbent retailers (Olswang, 2009). While on Tesco vs. Competitive Commission the economic cost of competitive proportionate test, while this can deprive customers of their benefit of expansion. The areas of Tesco complaint are the possible failure on the benefit of the competition test the account of the economic costs of the test when examining the proportionality of the test the ompetitive commission failed to take account. However, Tesco Victorious came as gap in competitive commission's analysis in relation to costs of competition test. On the Second ground of appeal that the CC's proportionality analysis was flawed, the margin of appreciation in terms of how to assess proportionality, and assessment supermarkets are also currently subject to a number of investigations under Chapter I of the Competition Act 1998 number of mergers in the sector have also been subject to scrutiny. Indeed, Tesco has recently been ordered by the $\mathrm{CC}$ to implement divestment remedies. Though the CAT verdicts for Tesco sound victorious it sound surprise and hard to believe. However, summarily Tesco was victorious (Olswang, 2009).

\subsubsection{Tesco Pricing Strategies}

Pricing Strategy is the setting of a bench mark on the worth's of a products or services. In setting pricing certain cost implication most be considered, these are (variable cost and Fixed cost). 'Fair Price' are guide to price fixing. While the calculative means of selling out the products/service to the market on a fit price and the willingness of the customers to pay is the strategy in the pricing (About.com, 2012). Pricing strategies are based on the situation and condition in the market with consciousness of economic and competitor's trend. Firms pricing strategies are adopted by managers based on the forces or system in the economy. The economic basis for each pricing strategy and how it can be implemented either in monopoly, monopolistic or oligopoly competitive market is determinant factor for firm existence. The profitability of any firm, and ability to survive the competing rivals in the industry, depends on the strategy adopted. Rivalry could be less and result to more profit in a concentrated industries with better strategy (Baye, 2010). Tesco viable Strategies of Sustainability are: quality products and services, innovative skill to customers, prompt response to consumer derives, improve customers' service and effective delivery, valued brand, improved Customers Services, promotional appeals, online market place initiative etc. pricing is key strategy to Tesco been an Oligopoly in a Grocery Market, "price is a rigid factor" that can't be temper with instead emphasis on value-added products to customers, launching of programs to spur customers etc (Tesco plc, 2012).

\subsubsection{Tesco, Non- Pricing Strategies.}

Non-Pricing Strategies is the conscious decision by business Firm to distinguish its products or Services as a strategy of selling distinct from their competitors even if price is fixed. This is one of the willingly effort embarked by Tesco, over the years by so sales and share increase, customers and potential customer also increases, Surmounting the rubric of oligopoly with price rigidity (Tags, 2011).Tesco's non-pricing strategies are relevant in the UK Grocery Market and other International subsidiaries of Tesco World Wide: these are: strategies for increasing market shares such as advertising, strategies for sales promotion policies, programs and appeals. The club card strategy earning points, such buy £5, earn 1 points strategy based on patronage and contribution of customers which serve as a burst, to spur commitment and loyalty of customers, creating value in the heart of their customers as a core purpose and earn life time loyalty, the Internet shopping and prompt delivery to customers branding, Packaging and Distribution, differentiation Strategy, the Magnetic Aided stripe card provides value information and other company profile. Other strategies includes: the online shopping, the prompt delivery, the magnetic aided stripe card which provide value information and other company profile. Tesco's vision is to satisfy and serve better, while continue remaining a giant and entry into new environment which is the utmost desire of a modern business (Revision Guru, 2012)

\section{Tesco Challenges of Non-Pricing Strategies.}

"The Big Price Campaign" In response to the strategies initiated by Tesco, Competitive rivals ( Asda and Sainsbury's "Alleged Tesco strategy of $10 \%$ cheaper than its competitors is not real" Instead, Tesco is "robbing Peter to pay Paul" ...Giving with the Right hand and taking with the left. First Tesco end up in "price war" and saves for Tesco much.(Smoke and mirror)."The Big Price Campaign" ' (Baker, 2011). At $£ 40$ "call $£ 5$ thank you voucher" While: The Asda reward for only grocery purchase at $£ 40$ "call $£ 5$ thank you voucher" the condition of the reward is stiff different items one most available at other super market a stringent time frame of redeem (Jones, 2011). Sainsbury emphasis is on brand match: Guarantee consumers to buy their products, if it could be cheaper at rivalry a back in voucher difference (Jones, 2011). 


\section{Tesco Club Card}

Tesco Club Card Collects Data on Customer behavior and retailer's ability to make the whole Shopping experience. Tesco's Card has advantage over its Competitors, such as buying trends and as results of Promotions, Sales uplift. Data collected by the Club Card Machine includes: New customers, existing Customers, brand-loyalist, buying habits of Customer in a branch, the repeated Purchase rates etc. and the products or service rendered in each branch and figure. This data give Tesco immediate and greater insight into their products and services. These capture Performances, Demand Ratio, and Figure etc. than market research. This aided Tesco to edge its competitors In the Oligopoly, UK Market (Humby, Hunt and Philips, 2010).

\subsubsection{Club Card Challenges.}

Inline to Tesco's rivals response on the "Big Price Campaign" and referred to "Club Card as "Smoke and Mirror". These undermine Club Card also: To Retain existing customers without card is cheap and cost effective and better strategies than card. While, unfortunately customers could also hold rivals 'cards and it consistently meets other appeals better off, example nectar card. However, the Club card generation relegates the use of approximation and focused market (Humby, Hunt and Philips, 2010).

\subsubsection{Demand Estimation and Club Card.}

Tesco Club Card influences Consumers buying habits by gaining more points as much purchases are made which results to Commitment/loyalty of consumers and since the higher the purchases the higher the points and vice versa. The points are motivator and inducement to the buyers, in line with demand estimation and the law of demand. Price and quantity demanded are inversely related. Club Card points rises (falls) and all other factors remain constant, the quantity demanded of Club Card products falls(rises) which is the market demand curve. Therefore: P0- P2 less Quantity p0-p1 high Quantity, Price movement along the trend. Depicting relationship between DD and Qty in the graph: Same could relate to Club Card points and the commitment/loyalty of Customers with Club Card. The theory relates to demand estimation (Baye, 2010). Demand Estimation and Theory of Demand.

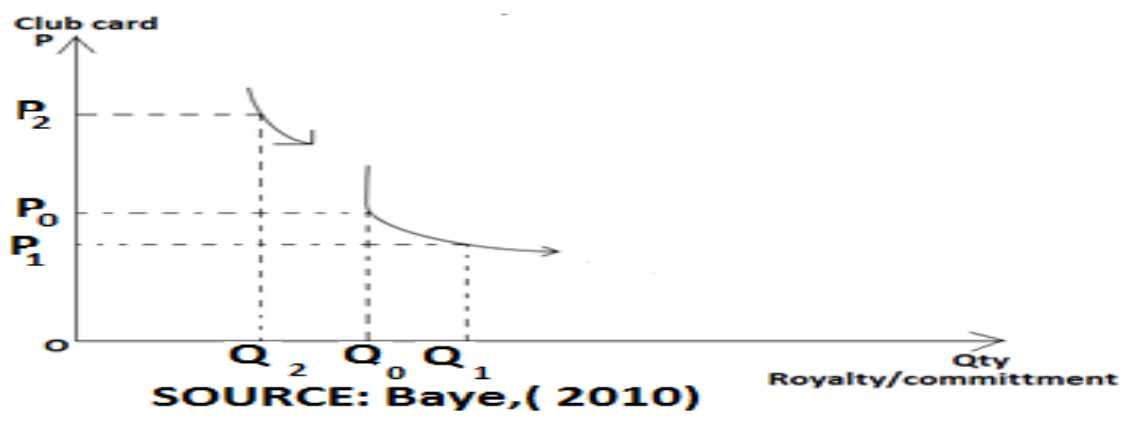

\subsubsection{Demand Theory relate to Club card Estimation.}

Tesco Club Card, attest to the loyalty and Commitment by Customers. The card is to ascertain customers Perceptions of club card, and feeling valued by customers and Identify which factor has the greater impact on customer loyalty (Jason and Wilson, 2006).

Share Price History for Tesco.

\begin{tabular}{|l|l|l|l|l|l|l|}
\hline Year- & Date & Open & High & Low & Close & Volume \\
\hline 2012 & (2Jan,2012) & 404.20 & 412.00 & 294.50 & ----- & $4,656,582,722$ \\
\hline 2011 & (3Jan,2011) & 431.55 & 439.90 & 348.95 & 403.45 & $4,262,425,638$ \\
\hline 2010 & (4Jan,2010) & 427.90 & 455.18 & 368.40 & 425.500 & $4,407,396,073$ \\
\hline 2009 & (2Jan,2009) & 360.00 & 437.05 & 301.40 & 423.00 & $5,534,386,583$ \\
\hline 2008 & (2Jan,2008) & 473.50 & 482.75 & 283.80 & 360.00 & $8,545,201,561$ \\
\hline & & & & & & \\
\hline
\end{tabular}

Source: Reuter, (2012) 


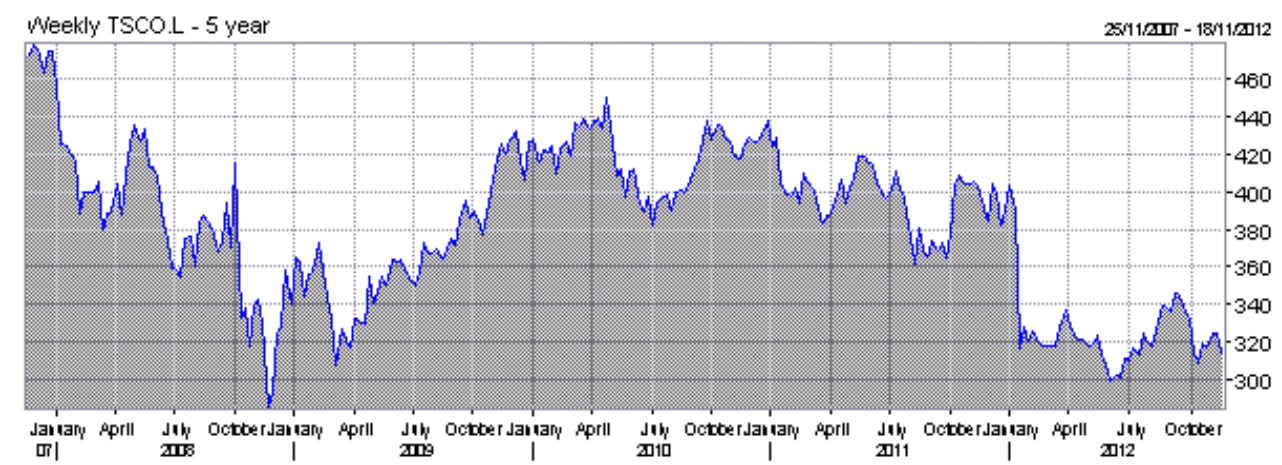

Source: Reuter, (2012).

\section{Reasons for Graphical Movement Tesco's for 5 years Period.}

The trend and movement indicates Tesco's Past Five years Period and Year 2012(January) with high value of $£ 482.75$ and the Share for the periods is $£ 113.5 \%$ (January2008). Calculate by Open value--Close Value $=$ Value Share. Reasons in the previous years: Recession trend on past years, for example the Economic Global Recession, Fluctuations in the economy, Low per capital income etc, which result to low consumption of consumers toward purchases and vice versa (Reuter, 2012)

\section{Share Price History for Morrison WM Supermarket.}

\begin{tabular}{|l|l|l|l|l|l|l|}
\hline Year- & Date & Open & High & Low & Close & Volume \\
\hline 2012 & (2Jan,2012) & 32.80 & 339.70 & 260.50 & ----- & $1,764,925,583$ \\
\hline 2011 & (3Jan,2011) & 269.10 & 326.20 & 261.70 & 326.20 & $2,028,212,588$ \\
\hline 2010 & (4Jan,2010) & 277.00 & 307.10 & 255.80 & 267.60 & $2,083,906,287$ \\
\hline 2009 & (2Jan,2009) & 279.75 & 298.45 & 233.50 & 274.40 & $2778,575,301$ \\
\hline 2008 & (2Jan,2008) & 321.50 & 324.25 & 210.75 & 280.25 & $3,778,632,860$ \\
\hline
\end{tabular}

Source: Reuter, (2012)

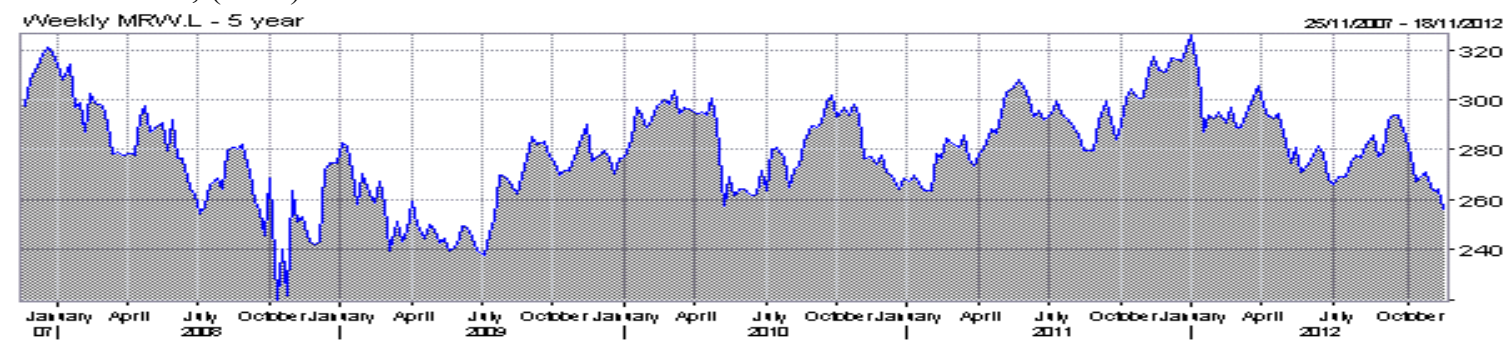

Source: Reuter, (2012).

\subsubsection{Reasons for Graphical Movement Morrison's for 5 years Period.}

The trend and movement indicates Morrison's Past Five years Period and Year 2012(January) with high value of $£ 339.70$ and the Share for the periods is $£ 41.25 \%$ (January2008). Calculate by Open value--Close Value $=$ Value Share. Reasons in the previous years: Recession trend on past years, for example the Economic Global Recession, Fluctuations in the economy, Low per capital income, which result to low consumption of consumers toward purchases and vice versa. : Reuter, (2012).

\subsubsection{Graph Indicates Trend and Movement of Sainsbury's for 5 Years.}

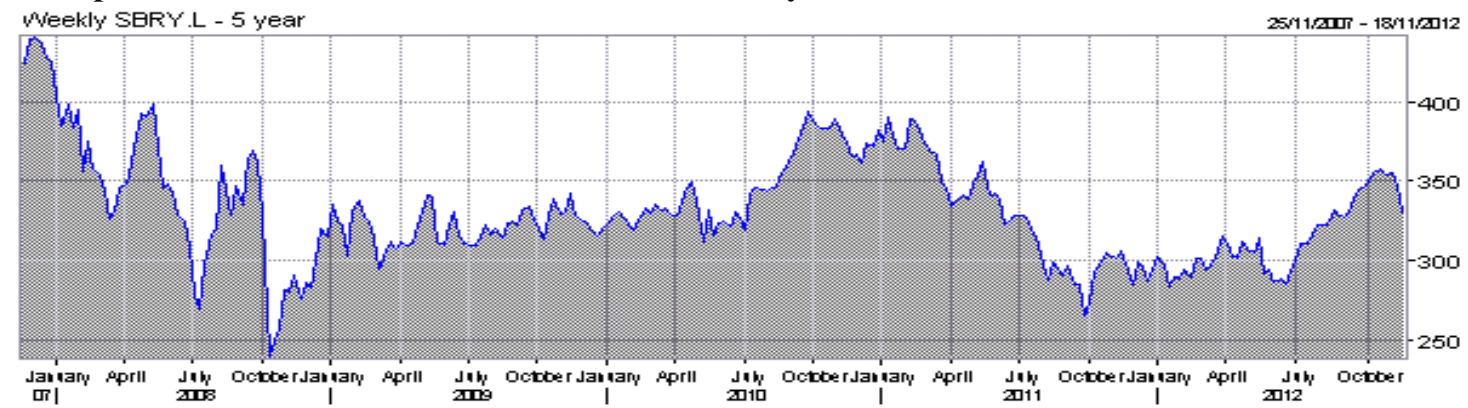

Source: Reuter, (2012). 
Share Price Performance Comparison With Ftse All Share Index.

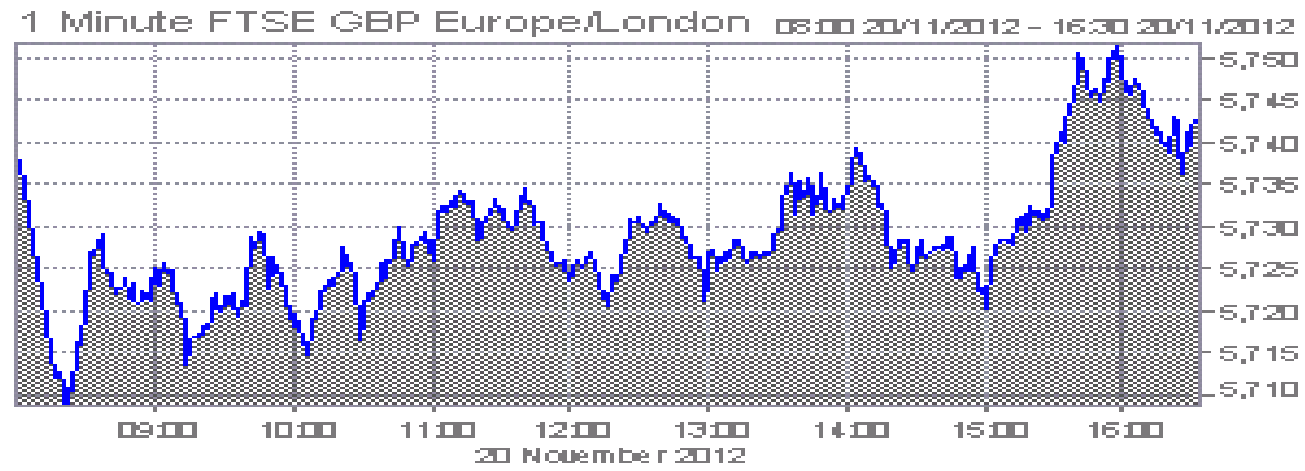

Source: Reuter, (2012).

\subsubsection{Share Price Performance and FTSE All-Share index.}

Based on the FTSE- ALL Share index in the London Stock Exchange five years trend and movement has raising and falling, both the FTSE and London Stock Exchange experiences sharp decline over period of time ( Recession) possible reasons: Global Melt down experience some years ago, resulted to low per capital income, inflationary rate affects the economy and decline in investment and saving (Reuter,2012).

\section{Global Market Share:}

Global Market Share is a Market for channelling; saving of the general public, corporates groups for a productive investment with a return of appreciation of capital and ultimately helps in the economic growth and development. Share investment for Firms can also be in derivatives products as future options, swaps, warrant, company assets etc. The Global Market Share mostly associated with share market investment through stock exchange were Stocks and bonds and other equivalent are traded between buyers and sellers in an organised and contractual market through network of dealer in a deal either Primary or Secondary Market . While Tesco belong to one of the leading Share Market in the World: The London Stock Exchange (Economy watch, 2010).

Tesco and Rivals International Global market Share 2010.

\begin{tabular}{|c|c|c|c|c|c|c|c|}
\hline $\begin{array}{l}\text { Top } 250 \\
\text { rank }\end{array}$ & Name or company & Country of origin & $\begin{array}{r}2010 \\
\text { retall sales } \\
\text { (US SmII) }\end{array}$ & $\begin{array}{l}2010 \text { retall } \\
\text { sales growth }\end{array}$ & $\begin{array}{r}2010 \\
\text { net prontt } \\
\text { margin }\end{array}$ & $\begin{array}{r}2010 \\
\text { return on } \\
\text { assets }\end{array}$ & $\begin{array}{l}2010 \text { asset } \\
\text { turnover }\end{array}$ \\
\hline 1 & Wal-Mart & u.s. & 418,952 & $3.4 \%$ & $4.0 \%$ & $9.4 \%$ & 2.3 \\
\hline 2 & Carrefour & France & 119,642 & $4.8 \%$ & $0.6 \%$ & $1.1 \%$ & 1.7 \\
\hline 3 & Tesco & U.K. & $92.171^{\circ}$ & $6.7 \%$ & $4.4 \%$ & $5.7 \%$ & 1.3 \\
\hline 4 & Metro & Germany & 88,931 & $2.8 \%$ & $1.4 \%$ & $2.7 \%$ & 1.9 \\
\hline 5 & Kroger & u.s. & 82,189 & $7.1 \%$ & 1.496 & $4.8 \%$ & 3.5 \\
\hline 6 & schworz & Germany & $79.119^{\circ}$ & $9.4 \%$ & $n / a$ & $n / a$ & $n / a$ \\
\hline 7 & Costco & u.s. & 76.255 & $9.1 \%$ & 1.796 & $5.6 \%$ & 3.3 \\
\hline 8 & The Home Depot & u.s. & 67,997 & $2.8 \%$ & $4.9 \%$ & $8.3 \%$ & 1.7 \\
\hline 9 & Walgreen co. & u.s. & 67,420 & $6.4 \%$ & 3.196 & $8.0 \%$ & 2.6 \\
\hline 10 & Aldl & Germany & $67.112^{\circ}$ & $5.2 \%$ & $n / a$ & $n / a$ & $n / a$ \\
\hline Top $10^{\circ}$ & & & $\$ 1,159,788$ & $5.0 \%$ & $3.0 \%$ & $6.4 \%$ & 2.1 \\
\hline TOP $250^{\circ}$ & & & $\$ 3,941,232$ & $5.3 \%$ & $3.8 \%$ & $5.8 \%$ & 1.5 \\
\hline
\end{tabular}

Deloitte, (2011).

\subsubsection{Concentration Ratio of Global Market:}

Schwarz $=79,119+$ Costco $=76,255+$ Kroger $=82,189+$ Tesco $=92,171 / 51,159,788 / 100=0.6 \%$. From the Graph of International Global Market Percentage: Schwarz (Germany) 9.4\% Highest: Second: Costco (US) $9.1 \%$, thirdly: Kroger (US) 7.1\% and fourthly Tesco 6.7\% in 2010 Global Assessment. Therefore by implication Tesco is the fourth in the World Grocery analysis (Deloitte, 2011).

\section{Reasons to Expand Retail Abroad:}

Growth and expansion are the objectives of business, to achieve these global opportunities Nations must be identify and pursue business intentions vigorously. Retaining image of home business and gaining global advantages and curtailing pressure on domestic rivalry competition for profits which could easily result to price "War" are among the reasons for business expanding international (Towers, et al., 2006).

Potential market leadership could occur were the firm is a resource based, a well multiform strategy and international entrepreneurial skills and consider cheap labour for example China. Therefore spreading risk in expansion becomes an opportunity for success and leadership. Putting all variables into consideration such as market, efficiency, regional diversification differences in all aspect before diversify and exploit the unexploited environment (Andidas, 2006). 


\subsubsection{Tesco Entry Strategy to International Market.}

The derive to enter international markets by Tesco to satisfied other subsidiaries nation and to equally increase market share, sales and profitability, has been the challenge. Tesco strategy to enter international like: Eastern Europe, Asia, China, Thailand, Japan, Czech Republic etc., was flexible a approached to succeed (Morrison, 2006).

Globalisation, and global best practices are universal, for example when Tesco entered into South Korea in 1999,it form a joints venture with Samsung, study the in-depth knowledge of the market, rented local stores, observe their local regulations and their preference taste products observed and hire their local staff, employing these strategies in the international market Tesco succeed (Tesco plc , 2006)

\subsubsection{Tesco Entry to new Geographic Market.}

Globalisation has aided business to adopt strategy that best fit and cost efficient toward survival in the new environment. Firm can enter international market through partnering wholly own or subsidiary acquisition (joint or equity venture). For example entry of Tesco into South Korea market .However, the choice of entry into international market is on the firm decisions, the best global practice strategy and then firm capability. Tesco strategy to these regions is summarized: Tesco approaches every entry with unique strategy in other to succeed in the whole region in Czech Republic for example in 1996 Tesco entered through acquisition of KMart stores, until 2010 when they franchise Zabka and Koruna stores combine global tendency with local realities and understanding local needs. Tesco strategy to these regions was conservative entry mode of store by store acquisitions: Small Stores of convenience Stores in Hungary, Super market in Poland, departmental Stores in Slovakia. Though, Strategy of entry succeed, but Tesco acquire relative small benefit, invariably startup capital are less and minimal risk (Tower, et al., 2006).

In conclusion, Tesco Plc, an example of Oligopoly, in the industry has been exposed in detail. Based on the Strategies analyse and other relevant economics, successful business decision are drawn.

\section{Reference List}

[1]. About.com, 2012. Economics, \{online\} Available at :>http://economics.about.com/cs/economicsglossary/l/bldefconcentrat.htm $>$

[2]. $\quad$ Accessed $12^{\text {th }}$ November, 2012\}.

[3]. About.com, 2012. Small Business $\quad$ Available at:>http://sbinfocanada.about.com/cs/businessplans/a/bizplanmarkplan_2.htm>

[4]. $\quad$ Accessed $22^{\text {nd }}$ November, 2012\}.

[5]. Akrani, G., 2010. Perfect Completion \{online\} Available at: $>$ http://kalyan-city.blogspot.co.uk/2010/11/perfect-competitionmeaning-and- main.html $>$ Accessed $21^{\text {st }}$ November, 2012\}.

[6]. Andida, 2006. Why do Companies go Global? \{Online $\}$ at : $>$ http://www.andidas.com/academic/lse_coursework/MN498\%20$\% 20$ Tesco\%20Internationalisation_by_andidas.pdf $>\left\{\right.$ Accessed $15^{\text {th }}$ November, 2012$\}$

[7]. Baker, J., 2012. Marketing Week $\{\bar{O}$ Online $\}$ Available:at $>$ http://www.marketingweek.co.uk/asda-and-sainsburys-slam-tescos-bigprice-drop/3030397.article[.> Accessed 21st November,2012\}.

[8]. Baye, M., (2010). Managerial Economics and Business Strategy, $7^{\text {th }}$ Edition, Mc Graw-Hill. [9]. Bentley, $\quad$ R., $\quad$ Stockbroker $\quad$ Avilable

[10]. Bentley,R.,2012.Stockbroker\{online\} Available at:>http://www.redmayne.co.uk/research/securitydetails/financials.htm?tkr=MRW $>\left\{\right.$ Accessed $12^{\text {th }}$ November,2012 $\}$.

[11]. Bentley, R., 2012 Stockbroker $\quad$ Aonline\}

$>$ http $/ /$ www.redmayne.co.uk/research/securitydetails/financials.htm?tkr=TSCO $>$ Accessed $11^{\text {th }}$ November, 2012\}

[12]. Deloitte, 2011. Global retail Perspective \{online\} Available at : $>$ https://www.deloitte.com/assets/DcomGlobal/Local\%20Assets/Documents/Consumer\%20Business/dtt_CBT_GPRetailing2012.pdf $>\left\{\right.$ Accessed $11^{\text {th }}$ November, 2012\}.

[13]. Economics online, 2012. \{Online\} Available at: $>$ http://economicsonline.co.uk/Business_economics/Oligopoly.html. $>$ Accessed on $12^{\text {th }}$ November, 2012

[14]. Economywatch, 2010. Global Market Shares \{online\} at:>http://www.economywatch.com/market/sharemarket/world/global.html $>$ Accessed 22nd November, 2012\}.

[15]. FinancialTimes,2012.Marketdata\{online\}

at:>http://markets.ft.com/research/Markets/Tearsheets/Summary?s=578076 $>$ \{Accessed $23^{\text {rd }}$ November, 2012$\}$.

Available

[16]. Humby, C.,Hunt, T. and Philips, T ., 2004. Scoring Point. Kogan page.

[17]. Humby, C.,Hunt, T. and Philips, T., (2010) Scoring points . Kogan page.

[18]. Humby C., Hunt, T. and Philips, T., (2008) Scoring Points.Kogan Page Limited London, $2^{\text {nd }}$ E dition.

[19]. IGD, 2012. IGD.COM \{online\} Available at:>http://www.igd.com/UK_Grocery_Retailing > [Accessed 12th November, 2012].

[20]. Jones, S., 2011. Msn \{online\} Available at :>http://money.uk.msn.com/your-financial-life/shopping-vouchers/asda-launches$\% \mathrm{C} 2 \%$ A35-voucher-scheme-and-3000-price-cuts $>$ A Accessed $20^{\text {th }}$ November, 2012$\}$ London $2^{\text {nd }}$ edition.

[21]. Kantar World Panel, 2012. \{Online\} Available at: $>$ kamcity.co.uk/namnews/asp/newsarticle.asp?newsid=67258. $>$ \{Accessed $25^{\text {th }}$ October, 2012\}.

[22]. Lowe, M.,2006.Aspect of Innovation in \{online\}@http://www.aimresearch.org/uploads/file/Presentations/Hidden_Innovation___MLowe.pdfn Available at:> \{Accessed $14^{\text {th }}$ November,2012\}.

[23]. Morrison, J.,2006. Global Business Environment. \{Online $\}$ at:>http://www.palgrave.com/business/morrisongbe3/students/casestudies/20\%20Finding\%20the\%20right $\% 20$ strategy $\% 20$ for $\% 20$ s etting\%20up\%20shop\%20in\%20Jampan.pdf $>$ \{Accessed $14^{\text {th }}$ November, 2012$\}$.

[24]. Nation Wide, 2012. \{online $\}$ Available at : $>$ http://uk.finance.yahoo.com/q/pr?s=TSCO. $>$ Accessed $14^{\text {th }}$ November,2012. 
[25]. Olswang, 2009.Changing Business \{online\} Available at :>http://www.olswang.com/articles/2009/09/the-cat-upholds-tescoschallenge- to-the-competition-commissions-groceries-market-investigation/ $>$ Accessed $10^{\text {th }}$ November, 2012$\}$.

[26]. Retail Week, 2012. Retail Week \{online\} Available at:>http://www.retail-week.com/sectors/food/tesco-and-morrisoncontinue->

[27]. $\quad$ Accessed $14^{\text {th }}$ November, 2012\}.

[28]. Reuter, T., 2012. The Guidance \{online\} Available at: $>$ http://www.guardian.co.uk/business/stock-search $>\left\{\right.$ Accessed $21^{\text {st }}$ November, 2012\}.

[29]. Rittenberg, L.,and Tregarthen,T.,1996. Microeconomics available at:>http://catalog.flatworldknowledge.com/bookhub/21? $=$ =rittenberg-> $\left\{\right.$ Accessed $13^{\text {th }}$ November,2012\}.

[30]. Revision Guru, 2012. Pricing and $\quad$ non-Pricing at:>http://www.revisionguru.co.uk/economics/pricestrat.htm $>\{$ Accessed14th November,2012\}.

[31]. Rugman, M. A., and Collinson, S.,2012. International Business Pearson Sixth Edition.

[32]. Skrainka, S.,B .2012. The Geography of Grocery Demand in the UK:\{online $\}$ Available at: $>$ http://papers.ssrn.com/sol3/papers.cfm?abstract_id=2061845 $>$ \{Accessed $10^{\text {th }}$ November,2012 $\}$.

[33]. SharePrice,2012. Shareprice.com \{ online $\}$ Available at:>http://shareprices.com/detail?tidm=MRW\&chart_time_period=2_day\&movingaveragetype=\&chart_comparison_tickers=\&start day $=10 \&$ startmonth $=01 \&$ startyear $=2008 \&$ endday $=10$ \&endmonth $=1 \overline{1}$ \&endyear $=2012 \&$ frequency $=$ yearly $>\quad\left\{\right.$ Accessed $\quad 11^{\text {th }}$ November,2012\}

[34]. Share Price, 2012

2012. SharePrice.com $\{$ online $\}$ Available at: $>$ http://shareprices.com/detail?tidm $=$ TSCO\&chart_time_period=2_day\&movingaveragetype $=\&$ chart_comparison_tickers $=\&$ start day $=10 \&$ startmonth $=01 \&$ startyear $=2008 \&$ endday $=10$ \&endmonth $=11$ \&endyear $=2012 \&$ frequency $=$ daily $>\quad\left\{\right.$ Accessed $11^{\text {th }}$ November, 2012$\}$.

[35]. SharePrice,2012.SharePrice.com $\{$ online $\}$ Availableat: $>$ http://shareprices.com/detail tidm=SBRY\&chart_time_period=2_day\&movi ngaveragetype $=\&$ chart_comparison_tickers $=\&$ startday $=10 \&$ startmonth $=01 \&$ startyear $=2008 \&$ endday $=10$ \&endmonth $=1 \overline{1} \&$ endyear $=2012 \&$ frequency=yearly $>\quad\left\{\right.$ Accessed $11^{\text {th }}$ November, 2012 $\}$.

[36]. Tags, M., 2011. Pricing and Non Pricing. \{online $\}$ at: $>$ http://www.skuuudle.com/blog/pricing-and-non-pricing-strategies-explained

[37]. Accessed 22 $2^{\text {nd }}$ November,2012\}.

[38]. Tesco plc, 2012. \{online $\}$ Available at : $>$ http://www.tescoplc.com/index.asp?pageid=17\&newsid=366>

[39]. $\quad$ Accessed 12 ${ }^{\text {th }}$ November,2012\}.

[40]. Tesco Plc, 2012. Annual Reports and Financial Statement. \{online $\}$ at: $>$ Accessed $22^{\text {nd }}$ October,2012\}.

[41]. Tesco, 2012.Tesco Submission to the competition commission inquiry into the UK Grocery Market .Pdf. Available at $<$ htt://www.tesco.com talking tesco/inc/Statement of case.pdf $<\left\{\right.$ Accessed $7^{\text {th }}$ November, 2012$\}$.

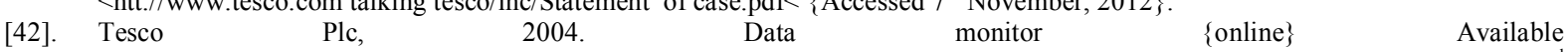
at:>http://people.exeter.ac.uk/wl203/BEAM011/Materials/Lecture\%204/TESCO\%20Com pany\%20Profile.pAccessed on 22 October,2012.

[43]. Tescoplc,2012.AboutUs $\{$ Online $\}$ Available at: $>$ http://www.tescoplc.com/index.asp?pageid $=6>\left\{\right.$ Accessed $25^{\text {th }}$ October, 2012].

[44]. Tescoplc,2006.Tesco'(online)Availableat: $>$ http://www.icmrindia.org/casestudies/catalogue/Business\%20Strategy/BSTR242.htm $>\{$ accessed $14^{\text {th }}$ November, 2012$\}$.

[45]. Turner, J.J., and Wilson, K., 2006. "Grocery loyalty:[e-journal]Available at:> Anglia Ruskin University Library website $<$ http://libweb.anglia.ac.uk> [Accessed 28th October,2012 ]. ", BritishFood Journal, Vol. 108 Iss: 11, pp.958 - 964. Emaerald Group Publishing.

[46]. Towers, e t al., 2006. InternationalMarketing \{online $\}$ Availableat: $>$ http://www.towers. fr/essays/Tesco-entering-retail-sector-inCentral-Europe-and-expansion-in-Czech-Republic.pdf $>$ \{ Accessed15th November,2012\}.

[47]. Thompson, J., and Martin, F., 2005 Strategic Management.Thomson Learning Published $5^{\text {th }}$ edition.

[48]. UTalk Marketin, 2008. \{online\} Available at: http://www.utalkmarketing.com/ $>\left\{\right.$ Accessed $22^{\text {nd }}$ October, 2012$\}$. 